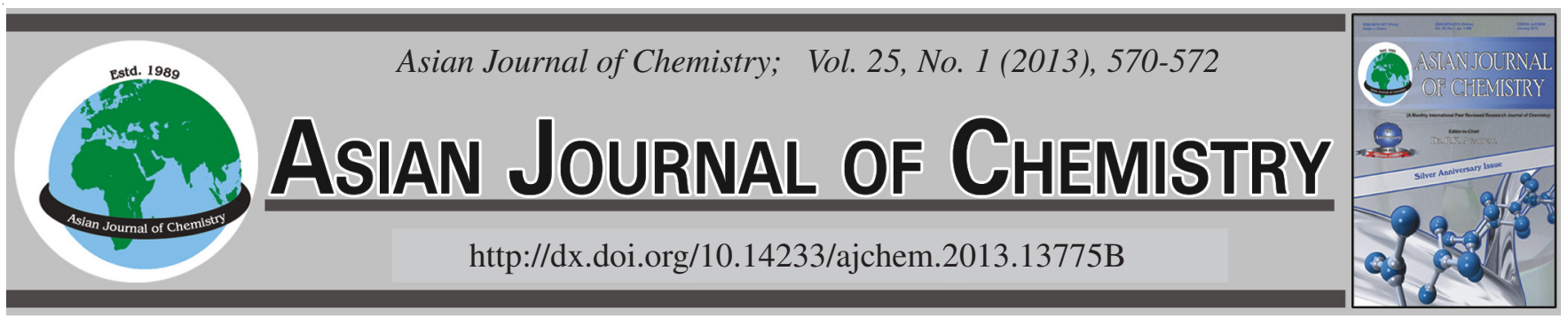

\title{
Spectrophotometric Determination of Strontium with Dibromo-p-chloro-chlorophosphonazo
}

\author{
Qing-Shuang Wang, Qing-Zhou Zhai ${ }^{*}$, XiaO-Xia Zhang and Ji-Qiang Li
}

Research Center for Nanotechnology, Changchun University of Science and Technology, 7186 Weixing Road, Changchun 130022, Jilin Province, P.R. China

*Corresponding author: Fax: +86 431 85383815; Tel: +86 431 85583118; E-mail: zhaiqingzhou@ 163.com, zhaiqingzhou@ hotmail.com

(Received: 22 March 2012;

Accepted: 7 August 2012)

AJC-11928

\begin{abstract}
Based on the complex reaction of dibromo-p-chloro-chlorophosphonazo (DBC-CPA) with strontium in the medium of $6.32 \times 10^{-2} \mathrm{~mol} / \mathrm{L}$ hydrochloric acid, this work established a simple, rapid and sensitive method for the determination of strontium by spectrophotometry. The maximum absorption peak of $\mathrm{Sr}^{2+}-(\mathrm{DBC}-\mathrm{CPA})$ complex locates at $620 \mathrm{~nm}$. At this wavelength, Beer's law is obeyed over the range of $0-2 \mu \mathrm{g} / \mathrm{mL}$ and its regression equation is: $\mathrm{A}=0.237 \mathrm{C}(\mathrm{C}: \mu \mathrm{g} / \mathrm{mL})+0.008$, with a correlation coefficient of 0.9991 . The apparent molar absorption coefficient of the method is $\varepsilon_{620 \mathrm{~mm}}=2.11 \times 10^{4} \mathrm{~L} \mathrm{~mol}^{-1} \mathrm{~cm}^{-1}$ and its detection limit is $0.234 \mu \mathrm{g} / \mathrm{mL}$. The composition of complex is $1: 2\left[n_{\mathrm{Sr}}^{2+}: \mathrm{n}_{(\mathrm{DBC}-\mathrm{CPA})}\right]$ obtained respectively by molar ratio method and the equimolar continuous variation method. The present method has been successfully applied to the determination of strontium contents in rain water and lake water. The relative standard deviation of 13 determinations was $1.28-3.90 \%$ and the recovery of the standard addition was $95.32-97.12 \%$.
\end{abstract}

Key Words: Dibromo-p-chloro-chlorophosphonazo, Spectrophotometry, Strontium, Water sample.

\section{INTRODUCTION}

Strontium is a special extensive element that exists in nature, also being a microamount element that human body is required. Metabolism of strontium in human body is extremely similar with that of calcium. It can accelerate metabolism of bones calcium and is a normal composition component of bones and teenth of a human body. Strontium is the same as $\mathrm{Ca}, \mathrm{Mg}, \mathrm{Si}, \mathrm{Li}$ and can reduce death ratio of heart blood vessel disease. Its mechanism is that $\mathrm{Sr}$ competes with $\mathrm{Na}$ in intestines and thus the absorption of sodium is reduced and the excretion of sodium is increased. Strontium contents in the hairs of coronary heart disease and lung heart disease patients are obviously lower than those of healthy people. Strontium in the soil and water of terra, where long life old people gather to reside, is obviously higher that that in contrast group area. All these show that strontium has a close relationship with maintaining the normal physiological functions. Strontium content of the whole blood of a normal person is $39 \mu \mathrm{g} / \mathrm{L}$. An adult person intakes $2 \mathrm{mg}$ of strontium every day, which can meet physiological need. Strontium content in food stuff is related to the strontium content of local water and soil. Therefore, analysis of strontium content has an important significance in geology, environmental protection, medicine domain, etc. Determination of strontium by spectrophotometry has the advantages of operation simplicity, cheap instrument price, etc., which caused people's great interests ${ }^{1}$. Arsenazo(III) $)^{2,3}$, dibromo- $p$ - methyl-chromosulfonazo ${ }^{4}$ and tribromoarsenazo ${ }^{5}$ chromogenic agents have been applied to the determination of strontium, but the selectivity of the methods is poor. Development of a new spectrophotometric method for the determination of strontium still has important significance.

Investigation of this paper is a spectrophotometric method for the determination of strontium using dibromo- $p$-chlorochlorophosphonazo(DBC-chlorophosphonazo, DBC-CPA). DBC-CPA, its full name is:2-(4-chloro-2-phosphonophenyl azo)-7-(2, 6-dibromo-4-chlorophenylazo)-1,8-dihydroxy-3,6naphthalene disufonic acid and its structure is as follows:<smiles>O=[N+]([O-])c1cc(Cl)ccc1N=Nc1c(S(=O)(=O)O)cc2cc(S(=O)(=O)O)c(N=Nc3c(Br)cc(Cl)cc3Br)c(O)c2c1O</smiles>

Fig. 1. Molecular structure of DBC-CPA

It can be known from Fig. 1 that on the aromatic ring in DBC-CPA there are $-\mathrm{OH},-\mathrm{SO}_{3} \mathrm{H}$ and $-\mathrm{PO}_{3} \mathrm{H}_{2}$ groups and the ring contains multiligands containing $\mathrm{N}, \mathrm{O}$. The reagent has stronger complex ability and can form water-solubility complex with metal ions. This article studied a colour reaction of the reagent with strontium(II). The results showed that in a dilute hydrogen chloride medium between DBC-CPA and $\mathrm{Sr}^{2+}$ a 
complex reaction occurs and a blue complex forms. A simple, fast and sensitive spectrophotometric method for the determination of strontium was established. The present method has been successfully used in the determination of the strontium contents in water samples. The operation of method is simple and convenient and the results are accurate.

\section{EXPERIMENTAL}

A 722S spectrophotometer (Shanghai Linggunag Technique Co. Ltd., China) equipped with $1 \mathrm{~cm}$ cell was used for measuring the absorbance.

All the chemicals and reagents used in this experiment were of analytical grade. Distilled water was used throughout the study.

DBC-chlorophosphonazo(DBC-CPA, Shanghai Changke Research Institute for Reagents, China); $1 \mathrm{~g} / \mathrm{L}$ aqueous solution. $\mathrm{Sr}^{2+}$ standard solution: $0.1685 \mathrm{~g}$ of $\mathrm{SrCO}_{3}$ (Beijing Chemical Plant, China) was placed in $30 \mathrm{~mL}$ of distilled water. $1 \mathrm{~mL}$ of concentrated hydrochloric acid (Beijing Chemical Plant, China) was carefully added to dissolve it. After the mixture was stirred to eliminate $\mathrm{CO}_{2}$, water was used to dilute to 100 $\mathrm{mL}$ and $1 \mathrm{mg} / \mathrm{mL}$ stock solution of $\mathrm{Sr}^{2+}$ was obtained. The working solution was obtained by dilution of the stock solution with distilled water. Its mass concentration was $10 \mu \mathrm{g} / \mathrm{mL}$. Hydrochloric acid (Beijing Chemical Plant, China) solution: $0.316 \mathrm{~mol} / \mathrm{L}$.

In a $10-\mathrm{mL}$ volumetric flask, $10 \mu \mathrm{g} / \mathrm{mL} \mathrm{Sr}^{2+}$ working solution, $2.0 \mathrm{~mL}$ of $0.316 \mathrm{~mol} / \mathrm{L}$ hydrogen chloride solution, $2.5 \mathrm{~mL}$ of $1.0 \mathrm{~g} / \mathrm{L}$ DBC-CPA solution was added in turn. The solution was diluted to the mark with water, shaken well. After $10 \mathrm{~min}$, using $1 \mathrm{~cm}$ cell, with the corresponding reagent blank as reference, the absorbance of colour solution was measured at $620 \mathrm{~nm}$.

Procedure for the determination of strontium in water sample: $100 \mathrm{~mL}$ of rainwater and lake water was accurately measured and taken and respectively placed in $250 \mathrm{~mL}$ beakers. $15 \mathrm{~mL}$ of concentrated $\mathrm{HNO}_{3}$ and $5 \mathrm{~mL}$ of concentrated $\mathrm{HCl}$ were respectively added and evaporated to near dryness on electric oven to destroy the organic substances in the water samples. After the solution was cooled down, 20 $\mathrm{mL}$ of distilled water was added. The solution was evaporated to dryness to eliminate possible residual disposal acids. Then, it was diluted with distilled water to the mark of a $100 \mathrm{~mL}$ volumetric flask as test solution. $1 \mathrm{~mL}$ of the test solution was taken and placed in a $10 \mathrm{~mL}$ volumetric falsk for strontium determination according to the general procedure. Then, recovery determination experiments were made and atomic absorption spectrometry was used for contrast determination. The above analytical results are presented in Table-1.

\section{RESULTS AND DISCUSSION}

Absorption spectra: According to the general procedure absorption curves are drawn and the results are seen in Fig. 2. Curve (a) is the absorption curve of reagent blank against water and its maximum absorption peak is $580 \mathrm{~nm}$. Curve (b) is the absorption curve of complex against reagent blank and its maximum absorption peak is $620 \mathrm{~nm}$. Thus, the present study selected $620 \mathrm{~nm}$ as the measurement wavelength.

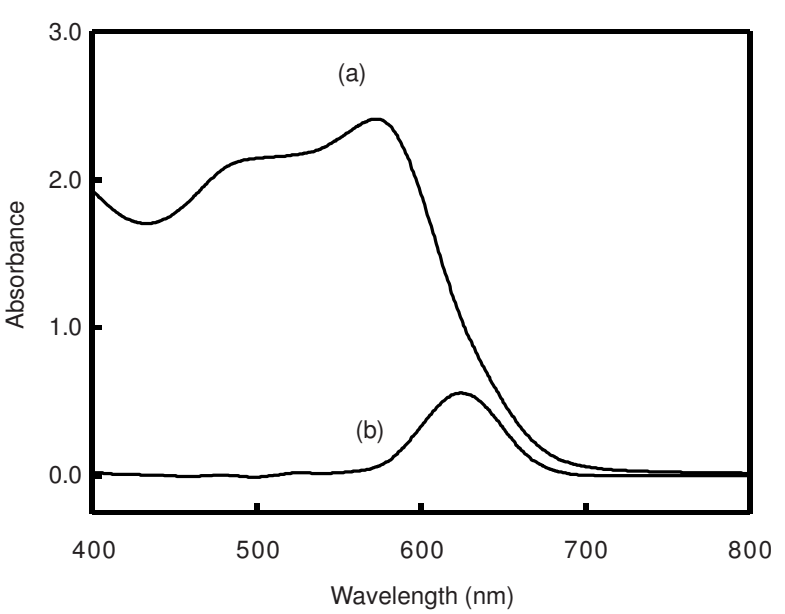

Fig. 2. Absorption spectra: (a) Reagent blank (vs. water); (b) complex (vs. reagent blank); $\left[\mathrm{Sr}^{2+}\right]=1.14 \times 10^{-5} \mathrm{~mol} / \mathrm{L} ;[\mathrm{DBC}-\mathrm{CPA}]=3.65 \times 10^{-}$ ${ }^{4} \mathrm{~mol} / \mathrm{L} ;[\mathrm{HCl}]=6.32 \times 10^{-2} \mathrm{~mol} / \mathrm{L}$

Optimization of experimental conditions: The experimental results of acidity effect indicated (Fig. 3) that the absorbance of complex in a medium of $[\mathrm{HCl}]=6.32 \times 10^{-2}$ $\mathrm{mol} / \mathrm{L}$ was maximum and the sensitivity was the highest. Hence, $6.32 \times 10^{-2} \mathrm{~mol} / \mathrm{L}$ of hydrochloric acid medium was taken as a reaction medium of formation of the complex.

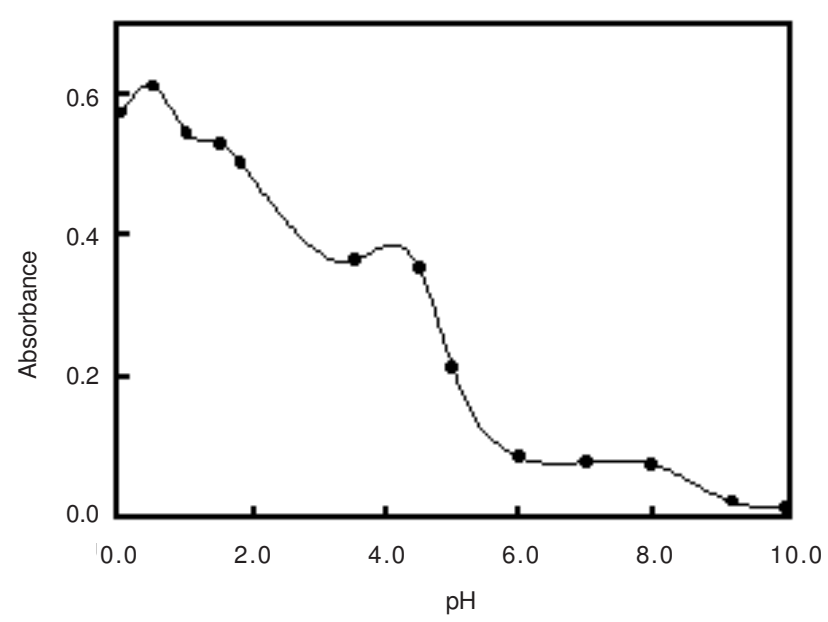

Fig. 3. Effect of acidity: $\left[\mathrm{Sr}^{2+}\right]=1.14 \times 10^{-5} \mathrm{~mol} / \mathrm{L} ;[\mathrm{DBC}-\mathrm{CPA}]=3.65 \times$ $10^{-4} \mathrm{~mol} / \mathrm{L}$

The effect of reagent concentration on absorbance of strontium(II) complex has been studied by adding various volume of reagent solution to sample solution containing $1 \mu \mathrm{g} / \mathrm{mL} \mathrm{Sr}^{2+}$. The results indicated that when amounts of $1 \mathrm{~g} / \mathrm{L}$ of DBC-CPA chromogenic agent were in the range of 2.2-2.8 $\mathrm{mL}$, the absorbance was maximum and stable. Therefore, $2.5 \mathrm{~mL}$ was used as optimum amount for measurement.

Order of addition reagent has no effect on the experimental results of complex formation. The order used in the experiment was: $\mathrm{Sr}^{2+}+\mathrm{HCl}+$ (DBC-CPA).

Composition and stability of complex: $\mathrm{Sr}^{2+}$ and DBCCPA form a blue complex in the acid medium. Molar ratio method and equal molar continuous variation method were respectively used to determine the composition ratio of complex to be $\mathrm{n}_{\mathrm{Sr}}{ }^{2+}: \mathrm{n}_{\text {DBC-CPA }}=1: 2$. 
TABLE-1

ANALYTICAL RESULTS OF SAMPLE

\begin{tabular}{|c|c|c|c|c|c|c|c|}
\hline Sample & Found $(n=13)(\mu \mathrm{g} / \mathrm{mL})$ & $\begin{array}{l}\text { Average } \\
(\mu \mathrm{g} / \mathrm{mL})\end{array}$ & $\begin{array}{c}\text { Relative } \\
\text { standard } \\
\text { deviation }(\%)\end{array}$ & $\begin{array}{l}\text { Added } \\
(\mu \mathrm{g} / \mathrm{mL})\end{array}$ & $\begin{array}{l}\text { Recovered } \\
(\mu \mathrm{g} / \mathrm{mL})\end{array}$ & $\begin{array}{l}\text { Recovery } \\
(\%)\end{array}$ & $\begin{array}{c}\text { Atomic } \\
\text { absorption } \\
\text { spectrometric } \\
\text { method }(\mu \mathrm{g} / \mathrm{g})\end{array}$ \\
\hline $\begin{array}{l}\text { Rain } \\
\text { water }\end{array}$ & $\begin{array}{c}1.695,1.781,1.728,1.682,1.768,1.672,1.726 \\
1.649,1.577,1.726,1.693,1.585,1.784\end{array}$ & 1.697 & 3.90 & 0.5000 & 0.4766 & 95.32 & 1.699 \\
\hline $\begin{array}{l}\text { Lake } \\
\text { water }\end{array}$ & $\begin{array}{c}4.210,4.131,4.105,4.116,4.189,4.204,4.153, \\
\quad 4.176,4.125,4.102,4.131,4.116,4.011\end{array}$ & 4.136 & 1.28 & 0.5000 & 0.4856 & 97.12 & 4.135 \\
\hline
\end{tabular}

The experimental results of complex stability showed that at room temperature strontium complex formed within $10 \mathrm{~min}$ and the absorbance reached a maximum. Within $22 \mathrm{~h}$ a variation of absorbance of the formed complex was less than $5 \%$ and the complex kept stable.

Analytical parameters: Calibration graph was constructed from spectrophotometric measurements performed under the optimum experimental conditions. The calibration graph was linear in the range of $0-20 \mu \mathrm{g}$ of $\mathrm{Sr}^{2+}$ in a volume of $10 \mathrm{~mL}$. The calibration equation is $\mathrm{A}=0.237 \mathrm{C}(\mathrm{C}: \mu \mathrm{g} / \mathrm{mL})+0.008$ with a correlation of $\gamma=0.9991$, where $\mathrm{A}$ is the absorbance determined at $620 \mathrm{~nm}$ and $\mathrm{C}$ is the concentration of $\mathrm{Sr}^{2+}$ in the sample solution in $\mu \mathrm{g} / \mathrm{mL}$. According to the working curve, the apparent molar absorptivity calculated is $\varepsilon_{620 \mathrm{~nm}}=2.11 \times$ $10^{4} \mathrm{~L} \mathrm{~mol}^{-1} \mathrm{~cm}^{-1}$. The relative standard deviation (RSD) for determination of $1 \mu \mathrm{g} / \mathrm{mL}$ of $\mathrm{Sr}^{2+}$ was $0.685 \%(\mathrm{n}=11)$, indicating that the precision of the method is excellent. The limit of detection, defined as $C_{L}=3 S_{b} / m$, where $C_{L}, S_{b}$ and $m$ are the limit of detection, standard deviation of the blank and the slope of the calibration graph, respectively, was $0.234 \mu \mathrm{g} / \mathrm{mL}$.

Selectivity of method: The effect of different cations and anions was investigated on the recovery of $1 \mu \mathrm{g} / \mathrm{mL}$ of $\mathrm{Sr}^{2+}$ by the proposed method, allowing relative error within $\pm 5 \%$. The following coexisting ions do not interfere with the determination $(\mu \mathrm{g}): \mathrm{K}^{+}, \mathrm{Na}^{+}, \mathrm{NO}_{3}{ }^{-}, \mathrm{SO}_{4}{ }^{2-}(4000) ; \mathrm{Ni}^{2+}, \mathrm{B}^{3+}, \mathrm{Br}^{-}, \mathrm{I}^{-}$ (1000); $\mathrm{Mg}^{2+}\left(1000,5000^{\mathrm{a}}\right) ; \mathrm{Li}^{+}, \mathrm{Mn}^{2+}, \mathrm{Hg}^{2+}, \mathrm{Cr}^{6+}, \mathrm{SO}_{3}{ }^{2-}(500)$; $\mathrm{Zn}^{2+}, \mathrm{Cu}^{2+}\left(300,600^{\mathrm{b}}\right) ; \mathrm{Cd}^{2+}, \mathrm{S}^{2-}, \mathrm{PO}_{4}^{3-}(200) ; \mathrm{W}^{6+}(100) ; \mathrm{NO}_{2}^{-}$, $\mathrm{CO}_{3}{ }^{2-}(50) ; \mathrm{Mo}^{6+}(25) ; \mathrm{F}^{-}(20) ; \mathrm{Ba}^{2+}(10), \mathrm{Al}^{3+}\left(10,20^{\mathrm{c}}, 100^{\mathrm{d}}\right)$, $\mathrm{Ag}^{+}(10) ; \mathrm{Hf}^{4+}(2.5) ; \mathrm{Cr}^{3+}(2) ; \mathrm{Pb}^{2+}, \mathrm{La}^{3+}(1) ; \mathrm{Fe}^{2+}\left(1,10^{\mathrm{e}}\right), \mathrm{Bi}^{3+}$, $\mathrm{Ti}^{4+}(1), \mathrm{Fe}^{3+}, \mathrm{Y}^{3+}, \mathrm{Th}^{4+}(0.5) ; \mathrm{Ca}^{2+}\left(0.1,0.5^{\mathrm{f}}\right), \mathrm{Ce}^{4+}(0.1)(\mathrm{a}, \mathrm{b}, \mathrm{c}$, $\mathrm{f}: 2 \mathrm{~mL}$ of $10 \mathrm{mg} / \mathrm{mL}$ EDTA was added; $\mathrm{d}, \mathrm{e}: 2 \mathrm{~mL}$ of $1 \%$ oxalic acid was added).

Sample analysis: In order to evaluate the analytical applicability of the proposed procedure, it was applied to the determination of strontium in water samples. The results are given in Table-1 that shows the excellent recoveries are obtained from the proposed procedure. The obtained results are in good agreement with those obtained by atomic absorption spectrometry. The obtained relative standard deviation values were $1.28-3.90 \%$ for 13 replicate measurements and the obtained recoveries were in the ranges of 95.32-97.12\%.

\section{Conclusion}

The present paper developed a new spectrophotometric method for the determination of strontium(II) with dibromo$p$-chloro-chlorophosphonazo and the strontium contents in rain water and lake water were successfully determined by the proposed method. At the maximum absorption wavelength 620 nm of $\mathrm{Sr}^{2+}$-(DBC-CPA) complex, Beer's law accords over the range of $0-2.0 \mu \mathrm{g} / \mathrm{mL} \mathrm{Sr}{ }^{2+}$ amount. The regression equation of working curve is: $\mathrm{A}=0.237 \mathrm{C}(\mathrm{C}: \mu \mathrm{g} / \mathrm{mL})+0.008$, with a correlated coefficient of $\gamma=0.9991$. The apparent molar absorptivity of method is $\varepsilon_{620 \mathrm{~mm}}=2.11 \times 10^{4} \mathrm{~L} \mathrm{~mol}^{-1} \mathrm{~cm}^{-1}$ and the limit of detection is $0.234 \mu \mathrm{g} / \mathrm{mL}$.

\section{REFERENCES}

1. H.Y. Yang, G.H. Yan and G.H. Zhong, PTCA, 43B, 424 (2007).

2. J. Du, J. Yu, Z.H. Liu and C.Y. Tao, Metal. Anal., 29, 61 (2009).

3. D.P. Liu, B.Y. Peng and S.L. Yang, Chin. J. Anal. Lab., 7, 54 (1988).

4. G.Z. Fang, S.M. Meng and G.Z. Zhang, J. Anal. Sci., 21, 66 (2005).

5. G.F. Huang and H.Y. Tian, Chin. J. Anal. Chem., 12, 314 (1996). 